\title{
Caffeine in teas: levels, transference to infusion and estimated intake
}

\author{
Silvia Amelia Verdiani TFOUNI ${ }^{1 *}$, Maíra Marcuci CAMARA ${ }^{1}$, Kamille KAMIKATA ${ }^{1}$, \\ Fernanda Moralez Leme GOMES ${ }^{1}$, Regina Prado Zanes FURLANI ${ }^{1}$
}

\begin{abstract}
Caffeine is naturally present in several foods, being one of the most consumed dietary ingredients in the world; however, excessive intake may cause health concerns. This study evaluated caffeine levels in teas and their infusions, the transference rate during brewing, and estimated caffeine intake from tea infusion. Brands and batches of 4 types of teas were analyzed for caffeine content by high performance liquid chromatography with a diode array detector. Mate tea was the one that presented lowest levels (6.1 to $13.2 \mathrm{mg} / \mathrm{g}$ ) while Camellia sinensis teas were from 14.3 to $34.8 \mathrm{mg} / \mathrm{g}$. There were statistical differences between different types, brands and batches. Caffeine levels in infusions followed the same pattern of the leaves, with mate tea presenting lowest levels. Caffeine percentage of transference from leaves to infusion varied from 51.5 to $85.2 \%$. Caffeine intake was estimated to be up to $191.4 \mathrm{mg} /$ day. Tea may be considered an important source of caffeine intake for heavy tea drinkers.
\end{abstract}

Keywords: xanthine alkaloid; mate tea; Camellia sinensis; HPLC; brew.

Practical Application: Caffeine levels in tea are carried to the infusion, which may be an important source of caffeine intake.

\section{Introduction}

Tea is one of the most consumed beverages in the world because of its pleasant taste, aroma, flavor and potential health-promoting properties. It gained its popularity in recent years mostly by the increased range of new flavors in the market and the several studies of tea healthy properties (Sadowska-Rociek et al., 2014; Godoy et al., 2013).

Tea health benefits have been widely studied and there are scientific evidences that tea intake can reduce cholesterol levels; reduce the risk of developing hypertension, immune disorders and Parkinson's disease; and protect against cancer, cardiovascular and nervous systems diseases. Additionally, it presents antioxidant, antimicrobial, anti-inflammatory, anti-allergy and anti-obesity effects (Wheeler \& Wheeler, 2004; Liu et al., 2000; Bae et al., 2015; Gramza-Michałowska et al., 2016; Rashid et al., 2016).

The composition of tea varies with the type of processing, leaves age, species, origin and climate. Moreover, each type of tea has its characteristic taste, health properties and different levels of caffeine. One of the main plants used as raw material for tea is Camellia sinensis from which green, white and black teas are obtained. The difference among them is how they are processed (Alonso, 1998; Sadowska-Rociek et al., 2014).

Green tea is not fermented and it is prepared from young leaves that are exposed to steam and high temperatures with the purpose to inactivate the oxidizing enzymes (Sajilata et al., 2008). Black tea is fully fermented and has a high level of caffeine, its preparation consists of the dehydration of the leaves and fresh stems, fermentation and drying through total evaporation of the water present on the leaves and stems. After this stage, leaves are fermented by enzymatic oxidation process and are exposed to high temperatures until acquiring a hard and crumbly consistency (Alonso, 1998; Balentine et al., 1997). White tea is the purest and it is submitted to a minimum amount of processing. White tea is an unfermented tea, it is prepared from young leaves picked before the buds have fully opened, and that did not suffer oxidation. The process consists of drying, dehydration and heating (Silva et al., 2012).

Mate tea, also known as yerba mate, is a traditional South America tea made from leaves of Ilex paraguariensis, and its process involves three steps: crushing, drying and toasting of the leaves (Silva et al., 2012).

Caffeine is a methylated xanthine alkaloid derivative identified as 1,3,7-trimethylxanthine and it is naturally present in several foods. According to a caffeine consumption review, it is one of the most consumed dietary ingredients in the world for which tea and coffee are the main prominent sources (Heckman et al., 2010). Caffeine can affect the tea quality characteristics, such as taste, contributing to the acidity and conferring astringency and bitterness (Farah \& Donangelo, 2006; Clifford, 1985). Several studies have reported the ability of caffeine to improve mood, attention, performance, alertness, speed at which information is processed and reaction time. In addition, a higher caffeine intake was associated with lower Parkinson's disease risk (Cysneiros et al., 2007; Dawkins et al., 2011; Liu et al., 2012; Peeling \& Dawson, 2007). 
Moderate caffeine consumption may bring some health benefits; however, excessive intake of caffeine can increase the risk of tachycardia, dehydration, anxiety, headaches, sleep disorders, nervousness, tremors, indigestion and dizziness (Ruxton, 2008; Gramza-Michałowska et al., 2016; Tefera et al., 2016). Over the years, different studies have been raising concerns related to its ingestion by specific groups, especially pregnant women, children and heavy coffee consumers (Knight et al., 2004; Fitt et al., 2013; Crozier et al., 2012). Nawrot et al. (2003) reported that, in healthy adults, a daily caffeine intake of up to $400 \mathrm{mg}$ day $^{-1}$ is not associated with adverse effects.

Since tea consumption is growing in Brazil and data regarding the quality of the product domestically marketed are still scarce, this study aims to evaluate the levels of caffeine in teas sold in Brazil and their infusions, the transference rate of this compound during brewing and estimate caffeine intake from tea infusion.

\section{Materials and methods}

\subsection{Reagents and chemicals}

Caffeine analytical standard was purchased from Sigma-Aldrich (St Louis, MO, USA). The following solvents (HPLC grade) and reagents were used in the analysis: methanol (J.T. Baker, Phillipsburg, NJ, USA), magnesium oxide, $\mathrm{NaH}_{2} \mathrm{PO}_{4}$, hydrochloric acid, ammonium hydroxide, zinc acetate and potassium ferrocyanide (Synth, Diadema, SP, Brazil), glacial acetic acid (J.T. Baker, Phillipsburg, NJ, USA) and phosphoric acid 85\% (Ecibra, Santo, SP). Agilent $0.45 \mu \mathrm{m}$ filters were used for filtering the extracts before the chromatograph injection. Water was purified on a Milli-Q system (Millipore Co., Milford, MA, USA).

\subsection{Samples}

Samples of industrialized teas leaves were purchased at stores located in the city of Campinas in São Paulo state. Samples analyzed were from 3 batches of tea types (mate, white, black and green) from 3 different brands, totalizing 36 samples of tea (leaves) as well as their respective infusions.

For the infusion sample preparation, $0.75 \mathrm{~g}$ of tea leaves was weighed and $100 \mathrm{~mL}$ of boiling water was added. The recipient remained covered for 3 minutes and subsequently the mixture was filtered.

\subsection{Method}

Method was based on the one described by Alves \& Bragagnolo (2002). The samples were homogenized and $0.5 \mathrm{~g}$ of tea (leaves) or $5.0 \mathrm{~mL}$ of the infusion were transferred to an Erlenmeyer flask and $1 \mathrm{~g}$ of magnesium oxide and $50 \mathrm{~mL}$ of water were added. The mixture was heated on a hot plate for 15 minutes with agitation. After heating, the mixture was cooled in a water bath at room temperature, filtered in filter paper in a $100 \mathrm{~mL}$ volumetric flask and volume was completed with water. Solution was filtered with a $0.45 \mu \mathrm{m}$ filter for further chromatographic analysis.

\subsection{Chromatographic analysis}

Analyses were carried out using a Shimadzu HPLC system equipped with a LC-20AT quaternary pump, in-line degasser, a Rheodyne $7725 \mathrm{i}$ injector ( $20 \mu \mathrm{L}$ sample loop), and a diode array detector SPD-M20A (detection at $272 \mathrm{~nm}$ ). LC solution software was used for data acquisition and processing. For separation, a C18 column (Merck Lichrosphere 100, $250 \mathrm{x} 4 \mathrm{~mm}, 5 \mu \mathrm{m}$ particle size) was used with a methanol:water (30:70) mobile phase at a flow rate of $1 \mathrm{~mL} / \mathrm{min}$. The compounds were quantified using external calibration curves. The analyses were performed in duplicate.

\subsection{Method validation}

Method was validated according to INMETRO (Instituto Nacional de Metrologia, Normalização e Qualidade Industrial, 2016) guidelines.

Triplicate HPLC injections of eight concentration levels $(0.001$ to $0.2 \mathrm{mg} / \mathrm{mL})$ of caffeine standard solutions, in water, were used to construct linear regressions lines. Accuracy and precision data were obtained through recovery studies where a chamomile tea was used as blank sample. Tests were carried out by spiking the blank sample with caffeine standard solutions at three concentration levels $(0.5,2.0$ and $3.0 \mathrm{~g} / 100 \mathrm{~g}$ and $0.003,0.02$ and $0.04 \mathrm{~g} / 100 \mathrm{~mL}$ for infusion) in six replicates. Precision of the method was evaluated through the relative standard deviation (RSD) of recovery analyses. The limits of detection (LOD) and quantification (LOQ) were estimated as 3.3 and 10 times, respectively, the ratio between the standard deviation of the blank response and the slope of the calibration curve.

\subsection{Statistical analysis}

Data was processed by analysis of variance one-way ANOVA with means comparison (Tukey test) with $95 \%$ confidence using software Statistica (Statistica 5.5, Stat Soft Inc.).

\subsection{Estimated intake}

In order to evaluate the exposure of the population to caffeine through the consumption of tea, the Survey on Household Budgets (Instituto Brasileiro de Geografia e Estatística, 2010) was used as source of information on tea consumption. The Survey on Household Budgets is a survey conducted by the Instituto Brasileiro de Geografia e Estatística (IBGE) among selected households covering urban and rural areas of all 27 Brazilian states, during 12 months (May 2008-May 2009). The survey presents the amount of food and beverage acquired for household consumption (per capita/year) by the Brazilian population of different geographical regions.

\section{Results and discussion}

Figure 1 presents chromatograms of tea leaves samples illustrating peak separation. Calibration curve obtained was linear, with a correlation coefficient of 0.9998. LOD, LOQ, recovery and precision obtained for caffeine analysis in teas are shown in Table 1. LOD and LOQ were 0.001 and $0.002 \mathrm{~g} / 100 \mathrm{~g}$ 

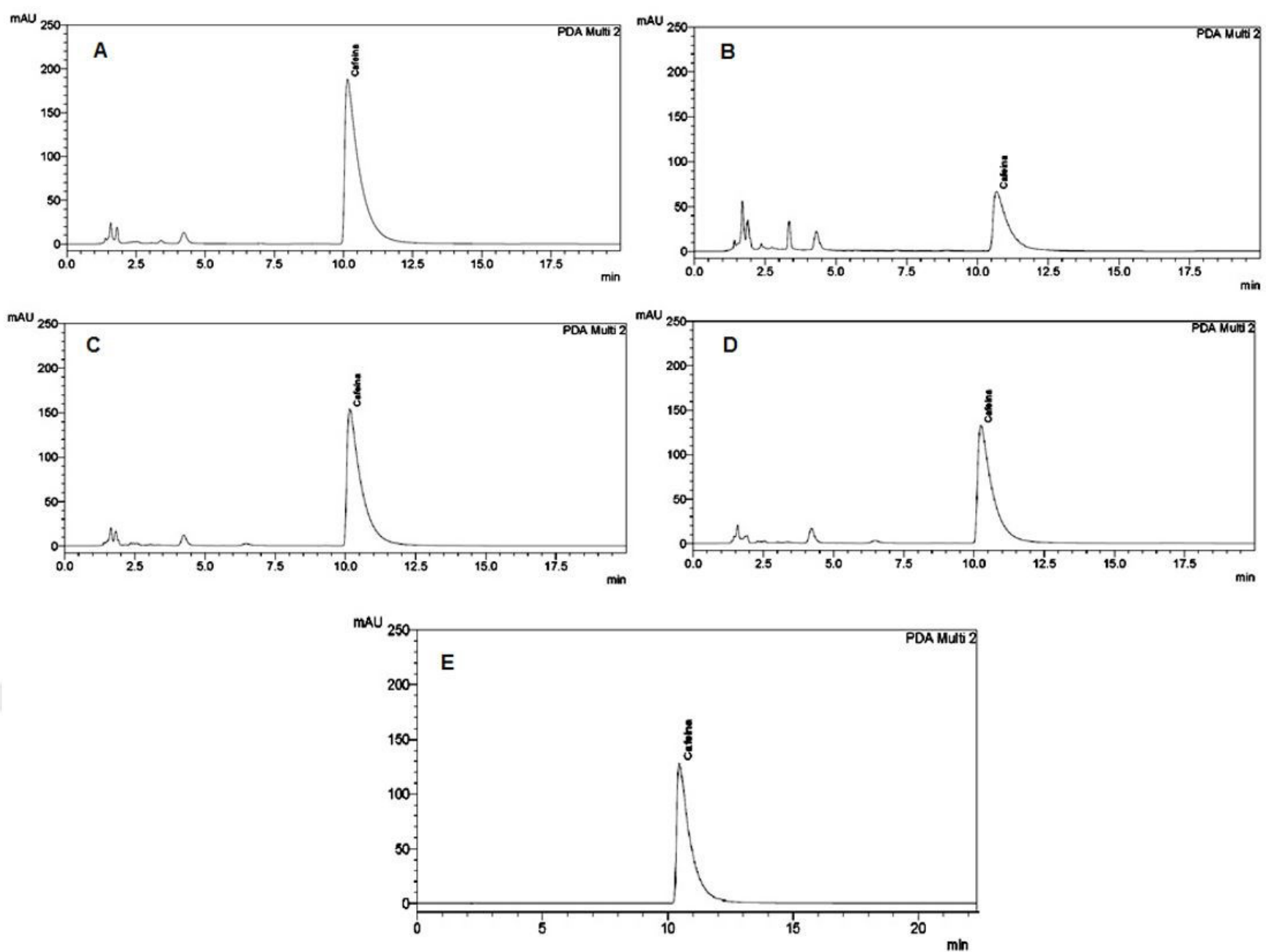

Figure 1. HPLC chromaotograms of white (A), mate (B), black (C) and green (D) teas and standard solution (E). C18 column (Merck Lichrosphere). Detection by UV $(272 \mathrm{~nm})$. Mobile phase: methanol:water (30:70), flow rate: $1 \mathrm{~mL} / \mathrm{min}$.

Table 1. Validation parameters (accuracy, precision (RSD), limits of detection (LOD) and quantification (LOQ)) for caffeine analysis in teas and infusions.

\begin{tabular}{cccccc}
\hline & LOD $^{1}$ & LOQ $^{1}$ & $\begin{array}{c}\text { Spike } \\
\text { level }\end{array}$ & $\begin{array}{c}\text { Recovery } \\
(\%)(\mathbf{n = 6})\end{array}$ & RSD (\%) \\
\hline $\begin{array}{c}\text { Tea } \\
\text { leaves }\end{array}$ & \multirow{2}{*}{0.001} & \multirow{2}{*}{0.002} & 0.5 & 97 & 0 \\
& & & 2.0 & 97 & 1 \\
& & & 3.0 & 98 & 2 \\
Infusion & \multirow{2}{*}{0.001} & \multirow{2}{*}{0.002} & 0.003 & 87 & 8 \\
& & & 0.02 & 92 & 1 \\
& & & 0.04 & 96 & 1 \\
\hline
\end{tabular}

${ }^{1} \mathrm{~g} / 100 \mathrm{~g}$ for tea leaves and $\mathrm{g} / 100 \mathrm{~mL}$ for infusion.

for tea leaves (g/100 $\mathrm{mL}$ for infusion), respectively. Recoveries ranged from $97 \%$ to $98 \%$ and $87 \%$ to $96 \%$, for leaves and infusion, respectively, while RSDs varied from $0 \%$ to $8 \%$. These results are considered satisfactory for determinations at the studied levels according to the criteria recommended by INMETRO (Instituto Nacional de Metrologia, Normalização e Qualidade Industrial, 2016).
Table 2 presents the average, minimum and maximum levels of caffeine in tea leaves samples. Mate tea was the one that presented lowest caffeine levels, from 6.1 to $13.2 \mathrm{mg} / \mathrm{g}$. On the other hand, white, green and black teas, from Camellia sinensis, presented higher levels ranging from 21.5 to $31.0 \mathrm{mg} / \mathrm{g}, 18.3$ to $25.3 \mathrm{mg} / \mathrm{g}$ and 14.3 to $34.8 \mathrm{mg} / \mathrm{g}$, respectively. These values are similar to the ones reported for other potential sources of caffeine intake. In roasted coffee beans Tfouni et al. (2012) detected caffeine levels ranging from 11.10 to $18.84 \mathrm{mg} / \mathrm{g}$. In guarana powder, which is usually used as a source of energy, caffeine levels may vary from 14.18 to $28.79 \mathrm{mg} / \mathrm{g}$ (Tfouni et al., 2007). Bae et al. (2015) reported similar results of caffeine levels in teas, $20.50 \mathrm{mg} / \mathrm{g}$ in green tea, $22.21 \mathrm{mg} / \mathrm{g}$ in black tea and $11.30 \mathrm{mg} / \mathrm{g}$ in mate tea.

By statistically analyzing the results obtained, one can verify that there are variations among different types of tea, different brands investigated and in some cases among different batches. According to the results obtained for leaves, mate tea showed statistical difference $(\mathrm{P}<0.05)$ in caffeine content, with levels being lower than the ones presented by the other teas. As for different brands from the same type of tea, there was no statistical difference $(\mathrm{P}<0.05)$ in caffeine levels between different brands 
Table 2. Levels of caffeine in tea samples (leaves and infusion) of different brands and batches, caffeine percentage of transference from leaves to infusion and average caffeine intake.

\begin{tabular}{|c|c|c|c|c|}
\hline \multirow{2}{*}{ Sample } & \multicolumn{2}{|c|}{ Caffeine $^{1}$ (range) } & \multirow{2}{*}{$\begin{array}{c}\text { Transference } \\
(\%)\end{array}$} & \multirow{2}{*}{$\begin{array}{c}\text { Caffeine intake } \\
(\mathrm{mg} / \text { day })^{2}\end{array}$} \\
\hline & Leaves $(\mathrm{mg} / \mathrm{g})$ & Infusion $(\mathrm{mg} / 100 \mathrm{~mL})$ & & \\
\hline Mate A & $6.2(6.1-6.4)$ & $4.0(3.7-4.2)$ & 85.2 & 7.3 \\
\hline Mate B & $8.4(7.2-9.4)$ & $5.1(4.1-6.2)$ & 80.9 & 9.3 \\
\hline Mate C & $10.8(9.4-13.2)$ & $6.8(6.3-7.7)$ & 84.9 & 12.4 \\
\hline Black A & $22.4(21.2-23.9)$ & $12.3(11.5-12.8)$ & 72.9 & 22.5 \\
\hline Black B & $31.7(23.6-34.8)$ & $14.9(13.1-18.1)$ & 64.4 & 27.2 \\
\hline Black C & $18.7(14.3-23.0)$ & $9.6(8.1-10.4)$ & 69.7 & 17.5 \\
\hline Green A & $21.8(19.9-23.5)$ & $11.8(11.5-12.1)$ & 72.7 & 21.5 \\
\hline Green B & $24.1(22.2-25.3)$ & $9.5(7.4-12.8)$ & 51.5 & 17.3 \\
\hline Green C & $20.4(18.3-22.0)$ & $10.9(9.5-12.1)$ & 71.9 & 19.9 \\
\hline White A & $30.1(29.1-31.0)$ & $14.1(12.4-15.4)$ & 62.5 & 25.7 \\
\hline White B & $26.4(25.4-27.3)$ & $12.5(7.9-14.9)$ & 75.6 & 22.8 \\
\hline White C & $23.2(21.5-26.2)$ & $10.5(9.2-12.7)$ & 60.4 & 19.2 \\
\hline
\end{tabular}

${ }^{1}$ Average of 3 batches in duplicate $(n=6) ;{ }^{2}$ Considering a consumption of $182.6 \mathrm{~mL}$ day ${ }^{-1}$ (Instituto Brasileiro de Geografia e Estatística, 2010).

of mate, green and black teas. White tea was the only one that showed significant difference among the evaluated brands. When considering different batches of the same brand, there was significant difference $(\mathrm{P}<0.05)$ in $42 \%$ of the cases. Difference were found in brands $\mathrm{B}$ and $\mathrm{C}$ of mate tea, brand $\mathrm{B}$ of black tea, brand $\mathrm{A}$ of green tea and brand $\mathrm{C}$ of white tea. These variations may occur because: a) teas commercialized in Brazil are usually a blend of teas from different origins and producers and b) caffeine occurs naturally in teas, and its content may vary according to the variety of plants, environmental growth conditions, seasonal variations and age of the leaves (Athayde et al., 2000; Heckman et al., 2010).

The caffeine levels in tea infusions and the percentage of transference from leaves to infusion during the preparation of the beverage were also evaluated. As can be seen on Table 1, the infusions followed the same pattern of the leaves, with mate tea presenting lower caffeine levels ( 3.7 to $7.7 \mathrm{mg} / 100 \mathrm{~mL}$ for infusion) than white (7.9 to $15.4 \mathrm{mg} / 100 \mathrm{~mL}$ ), green $(7.4$ to $12.8 \mathrm{mg} / 100 \mathrm{~mL}$ ) and black teas ( 8.1 to $18.1 \mathrm{mg} / 100 \mathrm{~mL}$ ). Although caffeine levels in the tea leaves and in roasted coffee beans are similar, the teas infusions present a much lower concentration than the ones reported for coffee brew, ranging from 87.3 to $192.0 \mathrm{mg} / 100 \mathrm{~mL}$ (Tfouni et al., 2014). This can be explained by the fact that coffee brew is usually prepared with a ratio of $50 \mathrm{~g}$ coffee to $100 \mathrm{~mL}$ of water, while for tea the ratio is of $0.75 \mathrm{~g}$ to $100 \mathrm{~mL}$. Results obtained in the present study are in accordance with the ones that have been reported by Rostagno et al. (2011), with an average of caffeine levels in mate tea of $4.0 \mathrm{mg} / 100 \mathrm{~mL}$, in white tea of $14.0 \mathrm{mg} / 100 \mathrm{~mL}$, in green tea of $13.0 \mathrm{mg} / 100 \mathrm{~mL}$ and in black tea of $8.9 \mathrm{mg} / 100 \mathrm{~mL}$.

As can be observed in Table 1, caffeine percentage of transference from leaves to the infusion varied from 51.5 to $85.2 \%$, with the highest rates of transference occurring in the mate tea samples ( 80.9 to $85.2 \%)$. As in this study time and temperature of the brewing were controlled, one possible explanation for these differences could be different sizes of tea particles which can vary among types and brands of tea, where smaller particles would facilitate caffeine extraction during infusion preparation.
In order to evaluate the exposure of the population to caffeine through the consumption of tea, an estimate of the intake of this substance was carried out based on the obtained results and tea consumption data. For this purpose, it was considered the average values of caffeine detected in the infusions and tea consumption data from the Survey on Household Budgets (Instituto Brasileiro de Geografia e Estatística, 2010). The average tea leaf consumption in Brazil according to IBGE (Instituto Brasileiro de Geografia e Estatística, 2010) is $0.50 \mathrm{~kg}$ per capita a year, which results in $182.6 \mathrm{~mL}$ of infusion per person a day. Taking in account this daily tea intake, the caffeine intakes from the different tea infusions analyzed would range from 7.3 to $27.2 \mathrm{mg} /$ person/day (Table 1). IBGE (Instituto Brasileiro de Geografia e Estatística, 2010) research also reports tea consumption by regions. Northeast is the region with lowest tea intake, $18 \mathrm{~g} /$ person/year, which is equivalent to a tea infusion intake of $6.6 \mathrm{~mL} /$ person/day. Considering the highest caffeine level detected $(18.1 \mathrm{mg} / 100 \mathrm{~mL})$, the Northeast population would have an estimated caffeine intake from tea of $1.2 \mathrm{mg} /$ person/day. On the other hand, the South region of the country is shown to be the largest tea leaf consumer, $2.894 \mathrm{~kg}$ per capita a year, corresponding to an infusion daily intake of $1.1 \mathrm{~L}$ per capita. When building a worst case scenario considering this consumption and the highest caffeine content, caffeine intake would be of $191.4 \mathrm{mg} /$ person/day.

The estimated intakes obtained are below the moderate daily intake of caffeine for healthy adults without adverse effects that is up to $400 \mathrm{mg} /$ day (equivalent to $6 \mathrm{mg} / \mathrm{kg}$ body weight/day for a $65 \mathrm{~kg}$ person) (Nawrot et al., 2003). However, considering that teas represent only one of the many caffeine sources in the diet, this intake could be of concern, especially for heavy drinkers.

\section{Conclusions}

The teas from Camellia sinensis presented higher levels of caffeine than mate tea. There were variations among types of tea, brands and batches; and a great part of caffeine present in the leaves was shown to be transferred to the infusion during preparation. The average daily intake of $263 \mathrm{~mL}$ of tea could contribute for an ingestion of up to $47.6 \mathrm{mg} \mathrm{day}^{-1}$ of caffeine on 
the diet. Although estimated daily intakes of caffeine from tea are lower than the ones estimated from coffee brew (198.2 to $435.8 \mathrm{mg}$ ) and guarana powder $(551 \mathrm{mg}$ ) (Tfouni et al., 2007, 2014), tea may be considered an important source of caffeine intake for heavy tea drinkers, being responsible, in the worst case scenario, for $48 \%$ of the daily intake without adverse effects $\left(400 \mathrm{mg}\right.$ day $\left.^{-1}\right)$.

\section{Acknowledgements}

Authors thank $\mathrm{CNPq}$ (Conselho Nacional de Desenvolvimento Científico e Tecnológico) for PIBIC/CNPq undergraduate student fellowships program.

\section{References}

Alonso, J. R. (1998). Tratado de fitomedicina: bases clínicas y farmacológicas. Buenos Aires: ISIS Ediciones.

Alves, A. B., \& Bragagnolo, N. (2002). Determinação simultânea de teobromina, teofilina e cafeína em chás por cromatografia líquida de alta eficiência. Revista Brasileira de Ciências Farmacêuticas Brazilian Journal of Pharmaceutical Sciences, 38(2), 237-243. http://dx.doi. org/10.1590/S1516-93322002000200013.

Athayde, M. L., Coelho, G. C., \& Schenkel, E. P. (2000). Caffeine and theobromine in epicuticular wax of Ilex paraguariensis A. St.-Hil. Phytochemistry, 55(7), 853-857. PMid:11190409. http://dx.doi. org/10.1016/S0031-9422(00)00324-1.

Bae, I. K., Ham, H. M., Jeong, M. H., Kim, D. H., \& Kim, H. J. (2015). Simultaneous determination of 15 phenolic compounds and caffeine in teas and mate using RP-HPLC/UV detection: method development and optimization of extraction process. Food Chemistry, 172, 469-475. PMid:25442580. http://dx.doi.org/10.1016/j.foodchem.2014.09.050.

Balentine, D. A., Wiseman, S. A., \& Bouwens, L. C. (1997). The chemistry of tea flavonoids. Critical Reviews in Food Science and Nutrition, 37(8), 693-704. PMid:9447270. http://dx.doi.org/10.1080/10408399709527797.

Clifford, M. N. (1985). Chlorogenic acids. In: R. J. Clarke, \& R. Macrae (Eds.), Coffee (Vol. 1, pp. 153-202). Amsterdam: Elsevier Applied Science. http://dx.doi.org/10.1007/978-94-009-4948-5_5.

Crozier, T. W. M., Stalmach, A., Lean, M. E. J., \& Crozier, A. (2012). Espresso coffees, caffeine and chlorogenic acid intake: potential health implications. Food \& Function, 3(1), 30-33. PMid:22130653. http://dx.doi.org/10.1039/C1FO10240K.

Cysneiros, R. M., Farkas, D., Harmatz, J. S., von Moltke, L. L., \& Greenblatt, D. J. (2007). Pharmacokinetic and pharmacodynamic interactions between zolpidem and caffeine. Clinical Pharmacology and Therapeutics, 82(1), 54-62. PMid:17443132. http://dx.doi. org/10.1038/sj.clpt.6100211.

Dawkins, L., Shahzad, F. Z., Ahmed, S. S., \& Edmonds, C. J. (2011). Expectation of having consumed caffeine can improve performance and mood. Appetite, 57(3), 597-600. PMid:21824504. http://dx.doi. org/10.1016/j.appet.2011.07.011.

Farah, A., \& Donangelo, C. M. (2006). Phenolic compounds in coffee. Brazilian Journal of Plant Physiology, 18(1), 23-36. http://dx.doi. org/10.1590/S1677-04202006000100003.

Fitt, E., Pell, D., \& Cole, D. (2013). Assessing caffeine intake in the United Kingdom diet. Food Chemistry, 140(3), 421-426. PMid:23601385. http://dx.doi.org/10.1016/j.foodchem.2012.07.092.

Godoy, R. C. B., Deliza, R., Gheno, L. B., Licodiedoff, S., Frizon, C. N. T., Ribani, R. H., \& Santos, G. G. (2013). Consumer perceptions, attitudes and acceptance of new and traditional mate tea products.
Food Research International, 53(2), 801-807. http://dx.doi.org/10.1016/j. foodres.2013.02.054.

Gramza-Michałowska, A., Kobus-Cisowska, J., Kmiecik, D., Korczak, J., Helak, B., Dziedzic, K., \& Górecka, D. (2016). Antioxidative potential, nutritional value and sensory profiles of confectionery fortified with green and yellow tea leaves (Camellia sinensis). Food Chemistry, 211, 448-454. PMid:27283654. http://dx.doi.org/10.1016/j. foodchem.2016.05.048.

Heckman, M. A., Weil, J., \& Gonzalez de Mejia, E. (2010). Caffeine (1, 3, 7-trimethylxanthine) in foods: A comprehensive review on consumption, functionality, safety, and regulatory matters. Journal of Food Science, 75(3), 77-87. PMid:20492310. http://dx.doi. org/10.1111/j.1750-3841.2010.01561.x.

Instituto Brasileiro de Geografia e Estatística - IBGE. (2010). Pesquisa de Orçamentos Familiares 2008-2009: análise do consumo alimentar pessoal no Brasil. Brasília: IBGE. Retrieved from http://biblioteca. ibge.gov.br/visualizacao/livros/liv50063.pdf

Instituto Nacional de Metrologia, Normalização e Qualidade Industrial INMETRO. (2016). Orientação sobre validação de métodos analíticos. Rio de Janeiro: INMETRO.

Knight, C. A., Knight, I., Mitchell, D. C., \& Zepp, J. E. (2004). Beverage caffeine intake in US consumers and subpopulations of interest: estimates from the share of intake panel survey. Food and Chemical Toxicology, 42(12), 1923-1930. PMid:15500929. http://dx.doi. org/10.1016/j.fct.2004.05.002.

Liu, R., Guo, X., Park, Y., Huang, X., Sinha, R., Freedman, N. D., Hollenbeck, A. R., Blair, A., \& Chen, H. (2012). Caffeine intake, smoking, and risk of Parkinson disease in men and women. American Journal of Epidemiology, 175(11), 1200-1207. PMid:22505763. http:// dx.doi.org/10.1093/aje/kwr451.

Liu, Z. Q., Ma, L. P., Zhou, B., Yang, L., \& Liu, Z. L. (2000). Antioxidative effects of green tea polyphenol on free radical initiated and photosensitized peroxidation of human low density lipoprotein. Chemistry and Physics of Lipids, 106(1), 53-63. PMid:10878235. http://dx.doi.org/10.1016/S0009-3084(00)00133-X.

Nawrot, P., Jordan, S., Eastwood, J., Rotstein, J., Hugenholtz, A., \& Feeley, M. (2003). Effects of caffeine on human health. Food Additives and Contaminants, 20(1), 1-30. PMid:12519715. http://dx.doi.org/10.1 080/0265203021000007840.

Peeling, P., \& Dawson, B. (2007). Influence of caffeine ingestion on perceived mood states, concentration, and arousal levels during a 75-min university lecture. Advances in Physiology Education, 31(4), 332-335. PMid:18057405. http://dx.doi.org/10.1152/advan.00003.2007.

Rashid, M. H., Chowdhury, M. A. Z., Fardous, Z., Tanvir, E. M., Pramanik, M. K., Jahan, I., Alam, M. K., Moniruzzaman, M., \& Gan, S. H. (2016). Microbial decontamination of gamma irradiated black tea and determination of major minerals in black tea, fresh tea leaves and tea garden soil. Lebensmittel-Wissenschaft + Technologie, 73, 185-190. http://dx.doi.org/10.1016/j.lwt.2016.05.044.

Rostagno, M. A., Manchón, N., D’Arrigo, M., Guillamón, E., Villares, A., García-Lafuente, A., Ramos, A., \& Martínez, J. A. (2011). Fast and simultaneous determination of phenolic compounds and caffeine in teas, mate, instant coffee, soft drink and energetic drink by highperformance liquid chromatography using a fused-core column. Analytica Chimica Acta, 685(2), 204-211. PMid:21168570. http:// dx.doi.org/10.1016/j.aca.2010.11.031.

Ruxton, C. H. S. (2008). The impact of caffeine on mood, cognitive function, performance and hydration: a review of benefits and risks. Nutrition Bulletin, 33(1), 15-25. http://dx.doi.org/10.1111/j.14673010.2007.00665.x. 
Sadowska-Rociek, A., Surma, M., \& Cieślik, E. (2014). Comparison of different modifications on QuEChERS sample preparation method for PAHs determination in black, green, red and white tea. Environmental Science and Pollution Research International, 21(2), 1326-1338. PMid:23900956. http://dx.doi.org/10.1007/ s11356-013-2022-1.

Sajilata, M. G., Bajaj, P. R., \& Singhal, R. S. (2008). Tea polyphenols as nutraceuticals. Comprehensive Reviews in Food Science and Food Safety, 7(3), 229-254. http://dx.doi.org/10.1111/j.1541-4337.2008.00043.x.

Silva, C. M. G., Braga, M. A., Sobral, V. R. V., Martinez, C. A. R., \& Carvalho, P. O. (2012). Avaliação da atividade antioxidante in vitro dos chás mate e verde antes e após a biotransformação por lipases. Brazilian Journal of Food and Nutrition, 23, 661-669.

Tefera, M., Geto, A., Tessema, M., \& Admassie, S. (2016). Simultaneous determination of caffeine and paracetamol by square wave voltammetry at poly(4-amino-3-hydroxynaphthalene sulfonic acid)-modified glassy carbon electrode. Food Chemistry, 210, 156-162. PMid:27211634. http://dx.doi.org/10.1016/j.foodchem.2016.04.106.
Tfouni, S. A. V., Camargo, M. C. R., Vitorino, S. H. P., Menegário, T. F., \& Toledo, M. C. D. F. (2007). Contribuição do guaraná em pó (Paullinia cupana) como fonte de cafeína na dieta. Revista de Nutrição, 20(1), 63-68. http://dx.doi.org/10.1590/S1415-52732007000100007.

Tfouni, S. A. V., Carreiro, L. B., Teles, C. R. A., Furlani, R. P. Z., Cipolli, K. M. V. A. B., \& Camargo, M. C. R. (2014). Caffeine and chlorogenic acids intake from coffee brew: Influence of roasting degree and brewing procedure. International Journal of Food Science \& Technology, 49(3), 747-752. http://dx.doi.org/10.1111/ijfs.12361.

Tfouni, S. A. V., Serrate, C. S., Carreiro, L. B., Camargo, M. C. R., Teles, C. R. A., Cipolli, K. M. V. A. B., \& Furlani, R. P. Z. (2012). Effect of roasting on chlorogenic acids, caffeine and polycyclic aromatic hydrocarbons levels in two Coffea cultivars: Coffea arabica cv. Catuaí Amarelo IAC-62 and Coffea canephora cv. Apoatã IAC-2258. International Journal of Food Science \& Technology, 47(2), 406-415. http://dx.doi.org/10.1111/j.1365-2621.2011.02854.x.

Wheeler, D. S., \& Wheeler, W. J. (2004). The medicinal chemistry of tea. Drug Development Research, 61(2), 45-65. http://dx.doi. org/10.1002/ddr.10341. 